\title{
Methodology of Da'wah to Lesbian, Gay, Bisexual And Transgender (LGBT): A Islamic Review
}

Sarah Nur Dalilah Kipayatu Allah, Wan Khairul Aiman Wan Mokhtar, Syaima' Syatirah Jaafar, Abdullah Ibrahim, Wan Mohd Khairul Firdaus Wan Khairuldin, Eusoff Amiruddin, Ahmad Safwan Jamaludin

To Link this Article: http://dx.doi.org/10.6007/IJARBSS/v10-i12/8214

DOI:10.6007/IJARBSS/v10-i12/8214

Received: 14 October 2020, Revised: 11 November 2020, Accepted: 28 November 2020

Published Online: 13 December 2020

In-Text Citation: (Allah et al., 2020)

To Cite this Article:Allah, S. N. D. K., Mokhtar, W. K. A. W., Jaafar, S. S., Ibrahim, A., Khairuldin, W. M. K. F. W., Amiruddin, E., \& Jamaludin, A. S. (2020). Methodology of Da'wah to Lesbian, Gay, Bisexual And Transgender (LGBT): A Islamic Review. International Journal of Academic Research in Business and Social Sciences, 10(12), 43-50.

\section{Copyright: @ 2020 The Author(s)}

Published by Human Resource Management Academic Research Society (www.hrmars.com)

This article is published under the Creative Commons Attribution (CC BY 4.0) license. Anyone may reproduce, distribute, translate and create derivative works of this article (for both commercial and non-commercial purposes), subject to full attribution to the original publication and authors. The full terms of this license may be seen at: http://creativecommons.org/licences/by/4.0/legalcode 


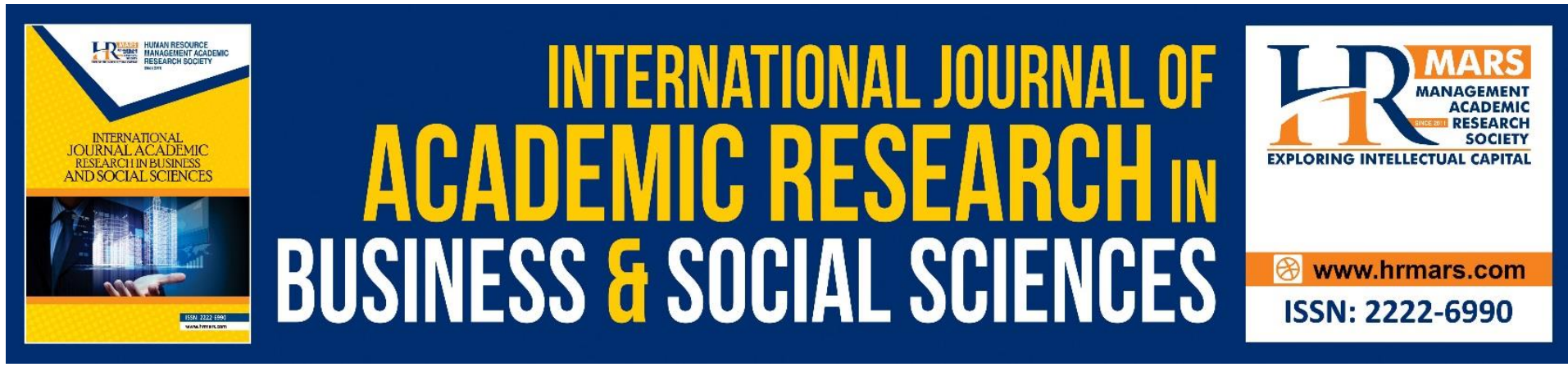

\title{
Methodology of Da'wah to Lesbian, Gay, Bisexual And Transgender (LGBT): A Islamic Review
}

\author{
Sarah Nur Dalilah Kipayatu Allah, Wan Khairul Aiman Wan \\ Mokhtar, Syaima' Syatirah Jaafar, Abdullah Ibrahim, Wan Mohd \\ Khairul Firdaus Wan Khairuldin, Eusoff Amiruddin, Ahmad \\ Safwan Jamaludin \\ Universiti Sultan Zainal Abidin (UniSZA), Kampus Gong Badak, 21300 Kuala Nerus, \\ Terengganu, Malaysia
}

\begin{abstract}
Da'wah is a program that is planned and can lead to the practice and appreciation of Islam in an individual. In Islam, da'wah is one of the recommended responsibilities of every Muslim whether or not it is individually or collectively. In addressing issues concerning lesbian, gay, bisexual and transgender (LGBT), the role of preachers is crucial to prove that Islam is able and can solve various social problems. The main focus of this article is to look at da'wah methodology on LGBT groups in Malaysia. This study is qualitative by using interview design and document analysis. The study found that there are five suitable methodologies of da'wah used for the LGBT group namely the bi al-hal dakwah methodology, entertainment, social construction, psychological approach and personality development. Therefore, assisting in this community group is the core in the context of the implementation of da'wah methodology towards LGBT groups.
\end{abstract}

Keywords: Da'wah Methodology, Lesbian, Gay, Bisexual, Trangander (LGBT), Firms of Charity Organization (PAFI)

\section{Introduction}

Lesbian, Gay, Bisexual, Transgender (LGBT) at this time already has its network around the world. Through this network, they are easy to promote their agendas and exchange information. The LGBT network has also been formed in Malaysia and continues to flourish in community life through the formation of NGO groups actively fighting for LGBT rights. While the way of life and the claims of the group is contrary to the principles of Islam and norms of normal human life, LGBT activities continue to flourish in today's society. One of the best approaches to controlling the transmission and proliferation of LGBT networks, especially among Muslims in Malaysia, is through da'wah activities. Therefore, every preacher should be sensitive to information about the development of LGBT and understand the appropriate methods used in missionary messaging activities that are intended to be truly accepted by the LGBT community. 


\section{Research Methodology}

Based on the type of research, this study was included in the library study. Data sources include reviews as the primary source. Although secondary sources include books, books, journals, and articles on Shari'ah as well as those relating to both, both from classical and modern scholarly works to finding relevant and actual meanings for the current context (Mokhtar, 2017).

\section{Findings and Research Discussion}

To discuss more about the methodology of da'wah lesbian, gay, biseksual and transgender (LGBT) then it is divided into two categories..The first, the introduction to Lesbian, Gay, Bisexual, Trangander (LGBT). The second, the concept of methodology of da'wah lesbian, gay, biseksual and transgender (LGBT).

\section{Malaysia and Lgbt}

The term LGBT refers to lesbian, gay, bi-sexual and trans-sexual acronyms. It stands for identification based on sexual orientation. Generally, their activities are related to human desire to change the origin of their occurrence to the opposite personality. In a contemporary context, LGBT is understood to be an active group or movement that helps and fights for their rights in today's society. Referring to the fourth edition of the Dewan Dictionary, the term gay is the male who has a sexual attraction to the like, homosexual men; lesbians refer to women who have sexual attraction towards the like, homosexual women; Bisexual is a person who has a tendency to have sex with men and women; Trans-sexual is a person (male or female) who acts as one of the other sexes, and sometimes changes the organ of the sex through surgery.

In addition, according to Blanch Consulting, lesbians are defined as a woman who is emotionally, sexually and physically attracted to other women (Halkitis et.al, 2009). According to Islamic perspectives, lesbians are known by the term musahaqah. As a result, lesbians are both inversely and externally between women and women. The gay term is also known as homosexuality is defined as a male who has sexual attraction towards the like (Hawkins, 2014). Gay also carries the same meaning as lesbian as the opposite and outside of the tabi'e practiced between men and men. Based on Sexual Orientation, Homosexuality and Bisexuality, the American Psychological Association (2013), bisexual means the practice of free sex between a male or female partner. The couple mentioned here include couples who have sex before marriage or married couples. Transgender occurs when an experienced person experiences discomfort with his or her sexuality (the sex anatomy).

The individual is said to have a desire and tendency to change the image of his body and his identity including way of life and behavior as the opposite sex for himself. Coyle and Kitzinger (2002) explain that the main characteristic of transgender or transexualism is a group that introduces themselves entirely to the opposite sex of their own birth. Transsexual men often assume that they are women who are trapped in men's bodies. In Malaysia, transexual terms are used to refer to male transversal namely men who want to be women, and as well as transsexuals women who want to be men in all aspects of life (Yik, 2001; Chlapoutaki \& Dinas, 2014).

In Malaysia, the term LGBT has begun to be used extensively on era 90s. Their movements aim to gain the rights of homosexual groups who are interested or have a sexual tendency towards the same sex. Due to the opposite the normal sex orientation, LGBT is a minority group in society. Nevertheless, the group actively promotes and excels themselves in an effort 
to claim the right rights in social life. The scenario in modern society life also shows that those who support the movement claiming homosexual rights are those who are recognized as human rights advocates and vice versa. As such, Ambiga Sreevanasan, who has dedicated his life to championing human rights and LGBT rights in Malaysia, has earned respect and received appreciation from various parties at the international level. He has received the International Women of Courage award in 2009 by the American government, and the French award-winning Chevalier de Legion d'Honneur (Knight of the Legion of Honor) from the French government.

The world's largest LGBT organization is the International Lesbian, Gay, Bisexual, Trans and Intersex Association (ILGA). ILGA embraces most LGBT organizations around the world who share a common goal. LGBT organizations around the world are actively championing their group's rights and collecting their members. At South East Asia as in Singapore, LGBT groups set up a group called People Like Us (PLU) to manage their activities while in Malaysia Seksualiti Merdeka group is seen as an organization that is actively promoting the LGBT agenda.

\section{Da'wah Methodology Against the Lgbt Group}

The methodology comes from the word method. The method means how to do something or system. There are several words in Arabic that are very close to its meaning with the method of uslūb, manhaj and isilah. Based on these meanings, the da'wah methodology means the study and systematic knowledge of the way of da'wah, or briefly referred to as knowledge or study of the way of da'wah. It can also be interpreted as a science of da'wah method or da'wah study (Zin, 2001).

Knowing the methodology in da'wah is very important and inseparable from da'wah activities. If the contents and messages of the da'wah are useful, then the methodology in preaching of da'wah is also not to be neglected (Zin, 2005: 5). It is also a measuring stick or determining effectiveness of da'wah done. The fundamentals associated with this da'wah methodology are mentioned in the words of Allah SWT which means:

"Call upon the way of your Lord with good wisdom and good lessons and defend them in a good way. Lo! Thy Lord knoweth best who is astray from His way, and He knows best the guided. "(Al-Naḥl, 16: 125).

The verse explains that the main thing that must exist in the Islamic dakwah methodology is by way of good intentions, lessons and advice, or by means of dialogue, good discussions and speeches (Zin 2005: 8). In addition, the last method of da'wah, the discussion or the speech in a good way (mujādalah ḥusna) is a da'wah method that can be applied to non-Muslim goons (Ibrahim, 1998: 5).

In delivering effective da'wah, the chosen methodology or approach must be appropriate and effective in order to attract da'wah targets. The mistake in selecting the appropriate methodology contributes to failure in da'wah activities being implemented. Therefore, in addressing the LGBT group, preachers should be able to choose the appropriate method in order to achieve the goal of da'wah. In Malaysia, the Charities of the Firdaus (PAFI) is a nongovernment missionary organization committed to devoting preachers to marginalized groups, those who have been discriminated against by society lesbian, gay, bisexual and transgender. Based on the interviews conducted by the missionary activist and president of the Firmausi Amanah Firdausi (PAFI), Mohd Rafi Bin Jaafar on July 7, 2015 and Hamli bin Hamdan on February 14, 2016, there are five methodologies that have been implemented by 
PAFI in preaching against the LGBT, the da'wah methodology bi al-hāl, da'wah methodology through entertainment, da'wah methodology through social construction and da'wah methodology through character development.

\section{Bi al-Hal Methodology}

Every daily behavior and practice of preachers and Muslims should reflect the sanctity of Islam that guarantees the well-being and peace of the universe. Each action will be viewed by the target for rating. In other words, behavior and daily action are a da'wah of al-hāl dakwah. Therefore, actions and behaviors must be based on the values of tauhid, in accordance with Islamic law, symbolizing the purity of Islam and in the form of invitation to the perfection of Islam (Berhanundin bin Abdullah 2009). Ethnologically, da'wah dakwah is a combination of the two words of the word dakwah and al-hāl. The word dakwah means calling, calling. While the word al-hâal means the situation. If the two words are linked then the dakwah of al-hāl contains the meaning of calling, invoking the state of affairs, or invoking, invoking the real act.Dakwah bil al-hāl is da'wah with the real act as done by Rasulullah SAW, it is proved that first came in Madinah is the construction of the Quba Mosque, uniting the Anshor and Muhajirin in the bond of ukhuwah islamiyah and so on (Muru'ah, 2000).

Dakwah bi al-hâal is usually implemented within the scope of application of Islamic values in the practice and way of life of a society. Therefore, dakwah bi al-haāl often focuses on building good morals in society. For example, implementing united practice, tolerance, good values, helping others, respecting others, and so forth. Often, preachers who practice dakwah bi alhâl need to reinforce themselves with good deeds, morals and values, before often misunderstanding da'wah targets. Inferiority, love sharing knowledge, understanding others' feelings and so on. Therefore, da'wah al-hal always focuses on building good morals in society. For example, the application of united practice, tolerance, good example values, mutual assistance, respect for others and others (Zain, 2001).

\section{The Methodology of Dakwah Through Entertainment}

Among the most popular elements of nature are entertainment or music art. Basically, Islam justifies its followers enjoying entertainment. Islamic entertainment is not limited to nasyid but it also includes other musical arts as long as it meets the criminals outlined by scholars'. The proponents of da'wah through entertainment art should be developed in a variety of forms, including creating alternative entertainment through the process of Islamic music art. Today, secular influences are becoming increasingly contagious in the art of music resulting in the enjoyable musical art of no longer seeking peace and devotion to God S.W.T, but it is merely to entertain, enjoy, liberate and want to be free from religious conviction. This music art is what led to evil because it lost its original purpose (Majid and Yusof, 2005).

Utilization of entertainment for the purpose of da'wah is an endeavor that everybody is serious about. This is because it is not just a matter of fulfilling the demands of human nature that wants peace and happiness, but it is seen to have a great potential in influencing the thinking and lifestyle of the community and thus creating the culture of a nation. In addition, he is also able to change the target thinking and behavior to something positive (Majid and Yusof, 2006). Through this approach, not just the Islamic message contained in the song lyrics that impacted the listeners, but the lifestyle, the appearance, the pattern of use, the entertainers are also their followers and idols. Hence, even though it is seen displaying the art of Islamic entertainment, at the same time many other messages that can be highlighted include, the fashion of Islam, the way of life of Islam, the Islamic religion and so forth. 
Entertainment that has been outlined by PAFI is through street or street music art approaches are busking that can provide useful messages to transgender people as well as communities in order to give them the opportunity to make good and beneficial perks. The form of songs wanted by PAFIs who have been nominated by PAFI should have interesting lyrics and have a nice and calm tempo to be heard. In the tempo of the song you want to be delivered from the mix of pop and jazz music. Not too hard and not too soft. The writer saw from the point that the current nasyid singer in Malaysia is still using the "slow tempo" element. This causes the listeners not to be interested in the message they want to convey. Indirectly all the efforts made through the entertainment dakwah are tidah succeed perfectly. Public acceptance nowadays is through the development of "pop and jazz" concepts. PAFI states that many programs through entertainment also help in terms of awareness of transgender people. Only what is needed is to improve in terms of other methods more effectively.

\section{The Da'wah Methodology Through Social Construction}

Ideally, people love to live together and to group. Humans can not be alone in all the time. Humans need each other to live. Human beings are social societies because humans are always interacting with each other (Thompson and DeBold 1971). Duplicate to build a human being to have a good relationship with God and fellow human beings, so that it is in a proper and balanced state. In a good relationship with the people, da'wah instructs Muslims to mix and interact with the good, help to equally uphold goodness and to avoid harm, to reproach and to advise among members to build justice and prosperity of life, to build an Islamic congregation and to live in intact fraternal bonds, such as a body. Previously, it has been touched that in social life, human beings are driven by the wants of the curious individual, racing to achieve something better.

Da'wah builds people in their social life with its own way. Organized social programs are in line with their social habits and become an encouragement to future generations. Through the authors' observation of the work movements undertaken by the PAFI that they have transformed community groups under PAFI's custody for more approaching community groups that are still unchanged so that they are influenced by the group. Maybe the transgender people who have not found this straight path will think that until they become this way. At the same time they will be confused about what has been done. Indirectly find a friend close to getting advice. It seems like a simple thing but has a big impact on da'wah targets.

Additionally, the PAFI encourages community groups who have turned to the benefit of following the charity programs conducted by PAFI voluntarily. People will be more welcome if they contribute more to the community. Among the voluntary programs organized by PAFI participated by these transgender groups are mutual support in indigenous villages, practicing in elderly care homes, as well as HIV / AIDS shelters. PAFI adopts a very unique concept of understanding "not looking for equality but to accommodate differences". Once the author sees and understands this concept, the author is aware that we as a society do not need to find similarities between these transgender groups. If we are busy looking for similarities between us and them, then we will see something negative to them. It is also necessary to address the differences between this community and the normal group. We have to share the differences between them so that they are easier for these people to understand what is necessary and does not feel awkward towards the community as the process of change towards goodness is running. 


\section{Conclusion}

LGBT is a group of people around the world. This group is considered a minority group which is not just living in the wrong way but also championing the way of life to be accepted by society globally. In the Islamic perspective, LGBT's movement and struggle are considered to be a struggle that violates religious principles and principles. However, in the context of the life of the majority Muslim community in Malaysia, the LGBT struggle is still actively carried out by this group either in the open or hidden. Therefore, activities da'wah should be strengthened and expanded in order not to occur in mad'u, especially minority groups such as LGBT groups. In addition, preachers should also use an effective and diverse approach in the process of delivering true Islamic living values to the LGBT group effectively. By adopting the approach adopted by the Charity Organization (PAFI), the study found that among the appropriate approaches used in da'wah activities in assisting the LGBT group was dakwah bi al-ḥāl, da'wah through entertainment, da'wah through social construction and da'wah through character development. In addition, preachers should also keep themselves away from judgmental and negative stigma of the group LGBT because it prefers the da'wah field and creates a gap between the da'wah agent and target group, the LGBT group.

\section{Acknowledgement}

This paper is founded on the research project of the Special Research Grant Scheme UniSZA/2017/SRGS/21 (Project No: R0019-R021). Special appreciation is owed to Ministry of Higher Education Malaysia (MOHE) and Universiti Sultan Zainal Abidin (UniSZA) for sponsoring and supporting this research.

\section{Corresponding Author}

Wan Khairul Aiman bin Wan Mokhtar (Ph.D), Senior Lecturer, Universiti Sultan Zainal Abidin (UniSZA), Kampus Gong Badak, 21300 Kuala Nerus. Tel: +609-6688776. Faks: +609-6687861. E-mail:wk_aiman@yahoo.com / wkhairulaiman@unisza.edu.my

\section{References}

Zin, A. A. M. (2001). Metodologi Dakwah. Kuala Lumpur: Penerbit Universiti Malaya. Hamzah, H. (1996). Kamus Melayu Global. Shah Alam: Piramid Perdana (M) Sdn. Bhd.

Rahman, K. A. (2015). Profil Masyarakat Melayu Malaysia di Media Sosial yang Mempromosikan LGBT: Isu-Isu Semasa Media dan Dakwah. Kuala Lumpur: Penerbit Universiti Malaya.

Coyle, A. E., \& Kitzinger, C. E. (2002). Lesbian and gay psychology: New perspectives. Blackwell Publishing.

Chlapoutaki, E., \& Dinas, K. D. (2014). Pedagogical Practices of Critical Media Literacy. Multilingual Academic Journal of Education and Social Sciences, 2(1), 70-83.

Miskawayh. (1966). Tahdhïb al-Akhlāq. Beirut.

Majid, M. K. (1988). Cabaran Umat Dewasa Ini: Suat Penyelesaian Menurut Islam. Kuala Lumpur: Fakulti Usuluddin Akademi Islam Universiti Malaya.

Mokhtar, W. K. A. W. (2017). Concept Al-Hadīth Al-Mawḍū'iy as A Method of Collecting and Analyzing Research's Data. International Journal of Academic Research in Business and Social Sciences, 7(2), 536-542.

Marbawi, M. R. (2006). Kamus Idris Marbawi Arab-Melayu. Kuala Lumpur: Darul Fikir.

Haridi, N. H. (2016). Metodologi Dakwah Terhadap Golongan LGBT: Analisis Terhadap Persatuan Amal Firdausi (PAFI). Bangi: Kolej Universiti Islam Selangor (KUIS). 
Siren, N. R. (2006). Dakwah Islam Semasa: Konsep dan Perlaksanaan. Kuala Lumpur: Universiti Malaya.

Halkitis, P. N. (2009). The Meanings and The Manifestations of Religion and Spirituality Among Lesbian, Bisexsual and Transgender. Journal Adult Development 16(2).

Ibrahim, A., Mokhtar, W. K. A. W., Ali, S., \& Simin, M. H. A. (2017). Effect of Transformational Principal Leadership Style on Teachers Commitments and School Achievement. International Journal of Academic Research in Business and Social Sciences, 7(5), 2222-6990.

Fadli, S. N. I. A., Mokhtar, W. K. A. W., Amiruddin, E., Rashid, R. A., Idris, M. F. H. M., \& Salleh, A. Z. (2019). Healthy Lifestyle of Prophet Muhammad SAW. International Journal Of Academic Research In Business And Social Sciences, 9(11).

Nafi, N. M., Mokhtar, W. K. A. W., \& Mustaffami, M. (2019). The Holy Quran Memorization in Globalization Era. International Journal Of Academic Research In Business And Social Sciences, 9(11).

Mokhtar, W. K. A. W., Saibi, S. N. S., Abd, N., Ghani, M. M. I., \& Wan, W. M. K. F. (2017). The Concept of Implementation and Application Enthronement of Judges in the Scheme of Memorizing Al-Quran, in the State of Terengganu Malaysia. International Journal of Academic Research in Business and Social Sciences, 7(2), 2222-6990.

Hamdan, S. S. B., Mokhtar, W. K. A. W., \& Imas, M. M. (2019). Prayer and Science (Research on the Main Prayer Movement). International Journal Of Academic Research In Business And Social Sciences, 9(11). 